\title{
The decomposition of economic outcomes as a result of changes in Brazil's male age-education structure
}

\author{
Ernesto F. L. Amaral \\ Universidade Federal de Minas Gerais, Brazil \\ eflamaral@gmail.com
}

\begin{abstract}
In Brazil, the age and education compositions of the male labor force is changing with great regional variation. Based on Demographic Census microdata, results indicate that cohort size has a negative impact on earnings, but this effect is decreasing over time. In this study we consider the impact on earnings by age and education, as well as estimated income inequality reduction and racial differentials. Fertility decline and improvements regarding educational attainment had a significant influence on the decline of income inequality in the country. Moreover, the nonwhite population has been experiencing less success in relation to educational achievement, compared to the white population.
\end{abstract}

\section{Keywords}

Age-education transition; cohort size; earnings profile; income inequality; race differentials; Brazil.

\section{Acknowledgements}

This research received support from the Brazilian Institute of Applied Economic Research (Instituto de Pesquisa Econômica Aplicada-IPEA) and the Coordination for the Improvement of Higher Education Personnel (Coordenação de Aperfeiçoamento de Pessoal de Nível Superior - CAPES) of the Brazilian Ministry of Education (Ministério da Educação - MEC), through a research scholarship on development (Cátedras IPEA/CAPES para o Desenvolvimento, 001/2010). I am grateful to Joseph E. Potter, Daniel S. Hamermesh, Eduardo L. G. Rios-Neto, Andrés Villarreal, as well as to the reviewers of this journal, for their valuable suggestions and comments. I would also like to thank Adriane Reams for editing this paper.

\section{Final publication}

Amaral EFL. 2012. "The decomposition of economic outcomes as a result of changes in Brazil's male age-education structure." Population Research and Policy Review, 31(6): 883-905. (http://dx.doi.org/10.1007/s11113-012-9245-6) 


\section{Introduction}

Recent literature analyzing the demographic dividend has focused on the impact of the decreasing dependency ratio on economic development (Bloom, Canning, and Malaney 2000; Bloom, Canning, and Sevilla 2003; Bloom and Freeman 1986; Bloom and Willliamson 1998; Higgins and Williamson 1997; Mason 2005; Mason and Feng 2005; Williamson 2003). In Brazil, the population is being effected by the decrease in the dependency ratio, but is also being significantly impacted by the vast regional variation that influences the age and education composition of the labor force (Alves 2008; Alves, Vasconcelos, and Carvalho 2010; Carvalho and Garcia 2003; Carvalho and Wong 1999; Moreira 2001; Potter, Schmertmann, and Cavenaghi 2002; Potter, Schmertmann, Assunção, Cavenaghi 2010; Queiroz and Turra 2010; Turra and Queiroz 2009; Wong and Carvalho 2005). Previous studies suggest that changes in age composition can have significant impacts on earnings. These impacts increase for individuals with more education (Berger 1985; Easterlin 1978; Freeman 1979; Triest, Sapozhnikov, and Sass 2006; Welch 1979). Earlier models were developed to verify whether the male compositional shifts in Brazil had an effect on workers' earnings (Amaral et al. 2007). Results indicated that the impact on earnings of the distribution of the male population in age-education groups is changing over time. The small proportional size of the least-educated groups does not have a significant impact on their earnings in more recent years. For groups with more education, the negative impact has been increasing over time with slight variations in more recent years.

The main consideration of this paper is that educational changes had a greater impact on earnings over time, than changes on age composition. Another hypothesis is that current income inequality in Brazil would be more severe if it had not undergone demographic and education transitions, because the country would have had a higher proportion of poorly educated people, 
as well as a large population of young people. Moreover, income inequality by race is an important factor that has to be taken into account to better understand the Brazilian labor market, since the white population is more economically stable, compared to the non-white population. In order to verify these hypotheses, this paper aims to: (1) measure separately the influence of age and education changes on earnings; (2) estimate Gini coefficients in order to measure the inequality of the income distribution among age-education groups; and (3) take into consideration racial differentials in male population distribution and earnings by age-education groups.

This study is organized into ten sections: (1) review of the debate about population growth and economic development; (2) discussion regarding the influence of age, experience, and cohort size on earnings; (3) review of recent Brazilian demographic transition; (4) explanation of data and regression models to analyze the effects of demographic and educational changes on earnings; (5) analysis of descriptive statistics about demographic and educational transitions in Brazil; (6) presentation of regression results; (7) decomposition of age and education impacts on earnings; (8) estimation of income inequality among age-education groups; (9) analysis of the male population distribution by race, as well as the distribution of earnings by race; and (10) final considerations.

\section{Population growth and economic development}

The relationship between population growth and economic development has been a reoccurring topic debated amongst scholars since the 18th century. The first scientific study about the impact of population size on the quality of life was done by Malthus in the classic "An Essay on the Principle of Population" (Malthus 1985). Malthus' main theory was that rapid 
population growth would not be followed by an increase in food production, because of fixed agricultural resources and slow technical progress. The result of such a trend would be the decline of the available diet below a subsistence level, to a point that population growth would be curbed by a high mortality rate.

The debate concerning population growth and economic development was mainly characterized by two different groups - the "traditionalists" and the "revisionists" (Kelley 2003). The traditionalists suggested that population growth was a threat to society, because of the decrease of both the per capita income and the economic growth. These researchers tended to analyze the consequences of population growth using a short-term approach, emphasizing the negative demographic and socioeconomic outcomes that population growth generates. On the other hand, revisionists analyzed population growth using a long-term approach. They generally examined the positive and negative impacts of population growth on demographic and economic variables. Moreover, revisionists analyzed how economic and political feedback, created by the society and government, would influence population growth. During the 1950s the revisionist approach was more common in the reports about population growth (Kelley 2003). During the 1960s and 1970s, the traditionalist view began to gain popularity within population literature and among the scientific community. However, since the 1980s, the analysis of population growth seems to have reverted back to a more revisionist perspective. The difference between each approach is not directly related to whether population growth is positive or negative. Even revisionists agree that significant population growth is not beneficial for developing or developed countries. The main issues that arise regarding the two approaches involves the revisionists' emphasis on a long-term analysis, positive and negative outcomes of change in age structure, and the importance of policies and practices implemented by different populations after this change. 
The theories of the traditionalists and revisionists focused on the influence of population size and growth on economic development, but little attention has been given to the impact of the changing age structure and how this structure changes when the population grows (Bloom et al. 2003). These authors point out the need to analyze changes in age structure and how it influences economic growth, since each population group has a different role within the economy. In developing countries, mortality and fertility rates started to fall at different levels after the 1950s, characterizing the demographic transition in those areas, where the people in working-age groups were growing proportionally to the dependent population. Because of these factors, many developing countries have the potential to observe economic development. However, if the appropriate government policies are not applied, developing countries might experience unemployment, instability, and suffer strains upon health services, educational attainment, and social welfare systems. Developing countries with transitional advantages, such as Southeast Asia and Latin America, have to implement policies to cope with the aging population, as well as take advantage of the remaining years of low dependency ratios (Bloom et al. 2003).

The decrease in the dependency ratio caused by rapid fertility decline has been shown to have influenced economic development in the countries of East and Southeast Asia (Bloom et al. 2000; Bloom et al. 2003; Bloom and Freeman 1986; Bloom and Williamson 1998; Higgins and Williamson 1997; Mason 2005; Mason and Feng 2005; Williamson 2003). The focus of those studies was on the shifting age distribution of the populations rather than the rate of population growth. The dependency ratio first increased after the mortality decline at the beginning of the demographic transition, but then fell after fertility began to decrease abruptly in those countries. This process has been called a "demographic dividend" whereby a changing age distribution allows for fewer investments in the youngest cohorts, enabling resources to be allocated for 
investments in economic development and family welfare. The higher proportion of people in adult age groups is a temporary effect since, after some decades, this population will age and the dependency ratio will again increase. Because of the temporary nature of the dependency ratio decrease, this process has also been called a "window of opportunity" (Carvalho and Wong 1999) for the implementation of specific policies to generate economic growth.

\section{Influence of age, experience and cohort size on earnings}

The first demographic dividend is determined by the direct impact of the age structure (ratio of working-age population to total population) on per-capita income. As is discussed above, the decline in the dependency ratio had positive impacts on the economic development of Asian countries that experienced rapid fertility decline. Since this literature is based on the influence of age and education compositions on economic outcomes, it is essential to highlight the connections involving schooling, experience, and earnings (Mincer 1974). Mincer was concerned about the estimation of earnings functions because previous studies solely utilized the linear impact of years of schooling on logged earnings. The observed correlation between education and earnings was not strong in those models, because variations in earnings associated with age were not captured. Hence, to expand the schooling model into a more complete earnings function, the linear schooling term must be improved by the use of a nonlinear years-ofexperience term. The use of experience is most appropriate when considering studies of female earnings. Studies focusing on male earnings would not be biased if age is used instead of experience, because this group is continuously attached to the labor force. The use of both years of schooling and experience as independent variables in earnings functions improve the results, 
with even better results when weeks worked during the year is included as an explanatory variable.

Further studies indicate that not only the independent impact of age and education explain earnings, but also cohort size. In other words, the productivity factor (ratio of total income to employment) can be affected by a shift in the population's age structure, generating a second demographic dividend. The productivity component can be exogenously influenced by shifts in the age and educational structures, according to the shape of the labor demand curve for each age and educational labor factor. Studies about influences of changes in age structure on earnings usually focus only on the male population. Women are usually excluded from analysis, partly because exogenous changes in age structure (fertility decline) and in educational attainment are significantly associated with female labor force participation.

The significance of fertility swings and shifting age distribution on economic development was analyzed in studies relating the influence of the "baby boom" on labor market outcomes in the United States (Easterlin 1978; Freeman 1979; Welch 1979). Cohorts born during the "baby boom" entered the American labor market between the end of the 1960s and the middle of the 1970s. The new labor force entrants had more schooling than earlier cohorts: (1) the number of persons with 5-8 years of schooling and with 1-3 years of high school fell considerably; (2) the number of high school graduates and those with at least some college increased significantly. Berger (1985) suggests that the negative effects of cohort size on earnings do not diminish rapidly, contrary to what Welch (1979) observes. Cohort size also has a negative effect on early career earnings growth, which is in opposition to Welch's findings. The impact of cohort size on earnings may actually increase throughout the careers of individuals belonging to large cohorts. 
Recent analyses regarding population aging and the structure of wages in the United States have been conducted (Triest et al. 2006). This study indicates that: (1) increases in relative cohort size are associated with decreases in wages; (2) although real wages initially increase with labor market experience, there is a significant decrease in the rate of growth as experience increases; (3) there was a general increase in economic return in relation to educational attainment; (4) changes in the age and experience composition of the labor force will continue to have an significant impact on the structure of wages; (5) the initial increase in the experience premium generated by a baby boomer's entry into the labor market is now being reversed as baby boomers progress through middle age and approach retirement. These authors imply that changes in the age and experience composition of the labor force will continue to notably influence the structure of wages. While these studies all refer to the case in the United States, they illustrate the power of the supply-demand framework and the richness of combining age and schooling as basic labor inputs, thus driving wage variations.

\section{Recent Brazilian demographic transition}

Since the 1970s Brazilian society has been experiencing a significant reduction in fertility rates (Alves 2008; Alves et al. 2010; Carvalho and Garcia 2003; Moreira 2001; Potter et al. 2002; Potter et al. 2010). This decline caused a significant reduction of the population growth rate, as well as a change in age structure in the country. Analyzing the interrelationships between age groups, both the child dependency ratio and the aged dependency ratio determined the decline of the total dependency ratio (Moreira 2001). The projection shows that the total dependency ratio will reach the minimum values between 2010 and 2020. This period, which will last until approximately 2025, is characterized as a "window of opportunity" (Carvalho and 
Wong 1999). These authors indicate that the opportunity to improve socioeconomic resources to focus on the young population and the possibility to plan policies in order to address the challenges of a growing elderly population are some of the necessary scenarios that Brazil will have to consider with the new age structure patterns.

In relation to the aging process of the Brazilian population, the proportional increase of older age groups is due to a fertility decline, rather than a mortality decline (Carvalho and Garcia 2003). The age distribution was constant until the 1960s and was characterized by a young population, in which 52 percent of the population was concentrated below 20 years of age and less than three percent was over 65 years of age. Following this period, mortality had a significant decline, mainly in the area of infant mortality.

Estimations and projections of the medium variant models from the United Nations (2006) show the trends of total fertility rate, infant mortality rate, life expectancy at birth (Table 1), and dependency ratios (Figure 1) in Brazil, between 1950 and 2050. The age distribution of the population of Brazil has been changing rapidly. Figure 1 shows the evolution of the child and old-age dependency ratios from 1950 to 2050. The child dependency ratio has fallen dramatically and will continue to decrease significantly in the next decades. However, the old-age dependency ratio has been increasing since 2000 and will increase even more in coming years. These patterns are related to the decline in the total fertility rate since the 1960s (Table 1). Since fertility declined so abruptly, the shares of younger age groups also declined.

\section{>> Table $1 \ll<$ \\ >> Figure $1<<<$}

The demographic transition can positively effect the economic development of Brazil (Alves 2008; Alves et al. 2010). This demographic bonus will result in economic growth only if 
the available labor force is absorbed by the market through the implementation of appropriate policies. Such policies should improve health services, educational attainment, and housing quality standards in order to promote economic development. After 2030, the demographic conditions will not be as favorable for this advancement, which can be observed by the increased projections in the dependency ratios. Brazilian society will face challenges as a result of the transition in age structure (Wong and Carvalho 2005). The window of opportunity experienced in Brazil will not result in an automatic solution to social problems, but by accounting for the new population dynamics innovative social policies can be implemented. Many of the demographic benefits that could have been explored have already been wasted because appropriate policies were not realized. The skill-set of the labor force should be improved, in order to promote higher productivity, as this group will be charged with the task of supporting the rapidly growing older population in the future. The elderly will drain resources through the use of the social security system and public health care. The window of opportunity has a short duration. This chance will go unutilized if reforms to policies for the older population are not applied and if programs for the younger population are not funded.

Studies have been developed about how the age structure interacts with the cycle of economic life, generating economic growth in Brazil (Queiroz and Turra 2010; Turra and Queiroz 2009). It was observed that the country did not take advantage of the demographic dividend potential in the last several decades. Even though population changes were not taken into account to implement economic growth policies, the demographic dividend explains 97 percent of the Gross Domestic Product per effective consumer between 1970 and 2010. These results indicate that Brazil's economic growth could have been even greater if policy makers had accounted for changes within the age structure of the population. 


\section{Data and regression models}

Beyond the national changes observed in Brazil, differences in the timing and speed of the fertility transition led to substantial temporal variations in age distribution across regions, states, and municipalities (Potter et al. 2002; Potter et al. 2010). The most accurate and accessible geographic identifier utilizing Brazilian Demographic Census microdata is the municipality (município), since information on districts (distritos), the sub-divisions of municípios, is not available. In previous work (Potter et al. 2002), minimum comparable areas were established, in order to account for the changing definitions and divisions of municipalities across the Census years. This procedure is necessary because the number of municipalities increased from approximately 2,300 in 1960 to 5,280 in 2000. The authors were able to aggregate minimum comparable areas into 502 micro-regions (groups of municipalities) across the five Censuses. It is important to note that these micro-regions differ from those defined by the Brazilian Institute of Geography and Statistics (IBGE) and those available in the Census microdata, but closely relate to those defined during the 1991 Census. It is thus possible to calculate various statistics summarizing the age distribution, labor-market outcomes, and educational indicators for each of these 502 consistently defined areas during each of the five Censuses.

During a previous analysis we classified the population into 12 age-education groups using the 1970, 1980, 1991, and 2000 Brazilian Demographic Censuses microdata (Amaral et al. 2007). Following this classification process, the distribution of the male population in each one of the 12 age-education groups for each one of the 502 micro-regions and four Census years was calculated. Finally, models estimated the impact on the logarithm of the mean real income of 
male workers in a group (dependent variable) by age-education-group indicators (12 dichotomous independent variables: 15-24 years and 0-4 years of schooling; 15-24 and 5-8; 15-24 and 9+; 25-34 and $0-4 ; 25-34$ and 5-8; 25-34 and 9+; 35-49 and 0-4; 35-49 and 5-8; 35-49 and 9+; 50-64 and 0-4; 50-64 and 5-8; 50-64 and 9+), age-education-group proportions, and Census years, using fixed effects for micro-regions.

In relation to the dependent variable, the significant information was the amount of income earned as a component of an individual's main occupation, since estimations dealt with the effect of changing age and educational composition on earnings in the labor market. For the 1980-2000 Censuses, information on earnings relating to an individual's main occupation was utilized. However, for the 1970 Census, information on total earnings was used because it was the only variable available. These data limitation did not affect the main results sought in this paper, which determined the effect of age-education-group proportions on earnings and not year indicators on earnings. All nominal amounts were calculated utilizing the currency as of January 2002. To account for currency changes, wages in 1970 and 1980 were divided by 2,750,000,000,000; and in 1991, they were divided by 2,750,000 (Corseuil and Foguel 2002). This correction was followed by the use of deflators suggested by the same authors (wages were then divided by 0.00000000000026439 in 1970; 0.0000000000057782 in 1980; 0.000067602304350 in 1991; and 0.902716061809642 in 2000).

Model (1) includes eleven indicators of age-education groups, taking the first ageeducation group as the reference; 12 proportions of men in age-education groups, called ownquantity effects; dummy variables for year, taking the 1970 census as the reference category; and 502 area fixed effects (Amaral et al. 2007). After determining this criteria, a model that allowed own-quantity effects to vary over time was estimated, called Model (1'). Model (2) allowed the 
proportion effects of each group to influence the other groups' earnings, called cross-quantity effects. Then, Model (2') allowed the cross-quantity effects to vary over time.

In this paper, I go beyond previous estimations (Amaral et al. 2007). More specifically, models (1), (1'), (2), and (2') were re-estimated by including interactions between the proportions in age-education groups with five major-region indicators: North, Northeast, Southeast, South, and Central-West. The number of coefficients in these new equations is very large. The new estimates generate a total of 67 coefficients in Model (1) following the addition of interactions with major-region indicators; 211 in Model (1') including the new interactions; 547 in Model (2); and 2,131 in Model (2').

\section{Descriptive results}

Table 2 shows the distribution of the male population by year and age-education groups in Brazil. In general, the numbers indicate that the proportion of men with zero to four years of schooling fell from 1970 to 2000. For example, the proportion of people between 15-24 years of age and 0-4 years of schooling dropped considerably from 28.19 percent in 1970 to 9.04 percent in 2000, a decrease of more than three times. Moreover, proportions of men with five to eight years of schooling, as well as those with at least nine years of schooling increased during the same period. The highest increases in proportion of men with at least nine years of education were the ones for individuals with 15-24 years, from 2.74 percent in 1970 to 10.24 percent in 2000, and for those with 35-49 years of age, from 1.59 to 8.46, during the same period.

\section{>> Table $2<<<$}

Figures 2 and 3 illustrate the proportion of males in two selected age-education groups for all 502 Brazilian micro-regions during the 1970-2000 Demographic Censuses. In order to 
calculate these proportions, only males ages 15-64 were considered in the denominator for each year and micro-region. For a better understanding of the figures, micro-regions are ordered by five Brazilian regions: North (NO), Northeast (NE), Southeast (SE), South (SO), and CentralWest $(\mathrm{CW})$. Figure 2 demonstrates the proportion of males with five to eight years of schooling and at least nine years of schooling in the 25-34 age group. There is a clear increase over time in the proportion of males with higher educational attainment. At the same time, differences among micro-regions are pronounced and persistent. Higher proportions in these age-education groups are observed in the Southeastern, Southern, and Central-Western areas, compared to Northern and Northeastern areas. Figure 3 demonstrates proportions of males in the lowest education group (0-4) in the 35-49 age group. In general, this figure shows that the proportion of males with zero to four years of schooling has been decreasing in all micro-regions. Areas in Southeastern and Southern Brazil show a greater decrease in the proportion of men in loweducated groups than do the North and Northeast.

\section{>> Figure $2<<<$ \\ >> Figure $3<<<$}

The changes in the distribution of educational attainment between the 1970 and 2000 Brazilian Demographic Censuses were substantial in all regions. Changes in the age distribution were also observed in the same period, at least in the Southeastern and Southern areas of the country. The crucial point is that along with profound demographic changes in Brazil over this period in both the age structure and educational attainment, these changes proceeded at different rates in different parts of the country. These variations allow us to identify the labor-demand parameters and thus to expand the study of the labor-market effects of the demographic dividend. 
Also, the persistent differences in levels suggest the need to use models that account for specific local factors through the use of fixed effects for micro-regions.

\section{Regression results}

The estimates show that predicted earnings from the model, that includes own-effects interacted with year (Model (1')) and major-region indicators, have patterns that follow much more closely with the ones of observed earnings. The new interactions with Model (2) and Model (2') did not improve significantly to conform to the observed variations. Even with statistically significant cross-effects observed in Models (2) and (2'), it seems that these effects do not have a great impact on earnings, generating predictions that do not better fit the data in comparison to those of own-effects models: Model (1) and Model (1'). More specifically, microregions located in the Northeastern region, an area which has been experiencing slower demographic and educational transitions compared to the Southeastern and Southern regions, have predicted earnings that better fit the data from the model that only includes own-effects interacted with region, rather than from the model that has cross-effects interacted with region. This is in line with previous studies - exogenous changes in the demographic structure of the labor force does not have a great effect on the relative wages of other groups (Hamermesh 1993).

The general conclusion from these models is that the impact of distribution of male population in age-education groups on earnings is changing over time. Positive elasticities are becoming negative for the least-educated groups, indicating that these groups are not benefiting from their small proportional size in more recent years. For better educated groups, the negative impact has been decreasing over time, but they are still statistically significant. While the labor 
market might have become more exigent in terms of workers' educational attainment, these shifts have not counterbalanced the effects of changes from age-education composition.

Table 3 illustrates the F-statistics that test whether all coefficients are equal to zero and whether the area fixed effects are equal to zero for the estimated models. The fraction of the variance due to the area fixed effects $\left(v_{i}\right)$ - Rho - is included in the table. The maximum number of possible observations in the regression is 24,096, because there are 502 micro-regions, 12 age-education groups and four Censuses. Because of the requirement that the cells should have at least 25 men receiving earnings, there were 19,727 observations throughout the models. In general, the statistics in Table 3 indicate that for models with fewer variables and consequently with fewer coefficients to be estimated, the $F$-statistics are larger. All models presented significant estimates, suggesting that the null hypothesis is not true. For the model with the highest number of independent variables $(2,630)$, including cross-proportions interacted with year and five major-region indicators; the fraction of variance due to the area fixed effects was 0.98 .

\section{>> Table $3<<<$}

Although the calculation of all variables used in the models took into account sample weights available in the microdata, weights were not used in the fixed-effects estimates. In other words, because fixed-effects models reflect relationships within micro-regions over time, between-micro-region sample variations are excluded from the analysis. In terms of this econometric matter, the appropriate weight to use in regression estimates should have been the square-root of the number of men with earnings in each micro-region, age, education, and year cell. Since the use of weights in a regression model is applied to all coefficients, including the constant, this would imply that the constant would vary for each micro-region over time. 
However, the use of weights is not allowed in fixed effects models, because the constant does not vary over time within the variable taken for fixed-effects estimates (in this case the microregion). A substantial problem might emerge in the regression models if the impact of proportions of men by age-education groups on earnings changes according to the population size of the micro-region. If the impact does not vary for different sizes of population in the areas, the new estimates will be similar to the original models. In this case, the interactions of proportions with micro-region-size indicators do not need to be included in the models.

As a strategy to take into account the influence that the different population sizes of micro-regions have on the prediction of earnings, indicators for size of micro-regions were included in the models, in the same way that regional indicators were included above. Microregions were divided into four groups defined by the quartile distribution of the male population receiving earnings for each year. Results of estimates in Models (1), (1'), (2), and (2'), including interactions between proportions of males in age-education groups with indicators of population size of micro-regions, suggest that the larger the micro-region, the greater the earnings. However, the new estimates suggest that predicted earnings do not change significantly from original Models (1), (1'), (2), and (2') after the inclusion of interactions with micro-region size. This finding might be a sign that original estimates fit the observed data well, even when not controlling for population size of micro-regions. These re-estimates confirm our models' assumption that different population sizes of micro-regions do not alter the impact of the ageeducation-group proportions on earnings.

Because the models were estimated at the local level, it is important to account for internal migration in the equations. Previous studies about the influence of changing age distribution on economic development did not incorporate the migration variable, because the 
analysis was done at the national level. Internal migration in Brazil is an important demographic component, since significant population streams from rural to urban areas occurred in previous decades. This migration is characterized by streams from areas of higher fertility rates to those of lower fertility. In other words, internal migration might reduce the differential in birth rates between rural and urban areas. However, this process might also increase the difference in dependency ratios, since migrants are concentrated within working ages. These specificities indicate that models would have to take into account the migration variable, in order to surmise the influence of age structure on economic development. New models estimated the impact of age and educational changes on workers' earnings, taking into account internal migration flows among micro-regions. The results indicate that the negative impact of cohort size on earnings would have been even more negative than estimates that did not include information on population flows. This implies that the previously estimated regressions do not overestimate the impact of age-education compositional changes on workers' earnings.

\section{Decomposition of age and education impacts on earnings}

After the estimation of the impact of changes in age-education groups on earnings, the decomposition of these effects provides insight about the separated impact of age and education changes. One can hold constant the age structure from the 1970 Demographic Census and use the education structure from the 2000 Demographic Census to estimate earnings in 2000. Comparing these new estimated earnings to the original 2000 predicted earnings (using age and education structures from 2000) measures the effect of changing age composition on earnings. For example, if age structure had remained the same from 1970 to 2000, one can compare these new results to the originally predicted 2000 values to verify that groups who experienced proportional 
increases over time (age-groups 25-34, 35-49, and 50-64) had original earnings that were less in 2000, compared to the earnings with constant age structure. When considering the opposite case, earnings in 2000 can be predicted utilizing the 1970 education structure and the 2000 age structure. These new estimated earnings can be compared to the earnings originally predicted in 2000 to analyze the impact of the changing educational composition on earnings.

First of all, national proportions of males by age-education group and Census year were used to generate two new sets of national proportions: (1) holding educational composition constant from 1970; and (2) holding age composition constant from 1970. In an additional step, these two new standardized compositions were used to forecast two sets of earnings by applying the coefficients from the own-effects model interacted with year indicators (Model (1')). Thus, Table 4 shows: (1) the 1970 predicted earnings, utilizing the actual 1970 age-education structure; (2) the predicted earnings in 2000, using the actual 2000 age-education distribution; (3) the predicted earnings in 2000, employing the actual educational composition of 2000, and the age structure in 1970; and (4) the predicted earnings in 2000, utilizing the actual age structure of 2000, and the educational composition of 1970.

\section{>> Table $4<<<$}

Analyzing the results in the third column of Table 4, one can see that mean real earnings would have been smaller for the youngest age group (15-24), when holding age composition constant, compared to original estimates (second column). Predicted earnings are greater for the other age groups compared to original estimates, because the aging process experienced by the Brazilian population increased the share of these age groups, with a result of even smaller originally predicted earnings (second column) compared to the case of age composition constant (third column). 
Results from estimates holding education constant from 1970 to 2000 (fourth column) indicate that, for groups with higher levels of education (five to eight years of schooling and at least nine years of schooling), earnings of these workers would have been larger than the original estimates at the end of the period. This provides evidence that the improvement in educational attainment over time increased the share of workers with better education, lowering their income. Groups in the lowest educational level (zero to four years of schooling) would have experienced a decrease in their earnings with a constant educational structure from 1970 to 2000, compared to original predictions. This fact is verified because since the groups with the lowest education represented a greater share in the 1970 population compared to the 2000 population, their earnings would have fallen considerably if they remained a significant portion of the population.

In general, results in Table 4 suggest that changes within the educational distribution generated the greatest impact on earnings over time. When holding 1970 educational composition constant (fourth column), the predicted earnings have values more unlike the originally predicted earnings of 2000 (second column) than when holding age composition constant (third column). Thus, by changing educational composition over time, within labor force ages (15-64), a greater impact on worker earnings was generated rather than changes in age structure.

Improvements in educational attainment generated lower earnings for more educated workers compared to the estimates holding education constant from 1970. However, an important result is that if the education had maintained constant over time, the lowest educated workers would have experienced even smaller earnings than illustrated by the original predictions. More specifically, the inequality of earnings between the least educated group (zero to four years of schooling) and the other educational groups, within each age group, would have 
been even greater than the one predicted using the age-education composition in 2000 . Thus, the improvement in educational attainment from 1970 to 2000 was an important aspect towards reducing economic inequality in Brazil.

Moreover, changes in age structure also decreased earnings inequality between the youngest age group (15-24) compared to the other age groups. This assessment is supported by the finding that mean real earnings would have been smaller for the youngest age group and bigger for the other ones, if the age composition had remained the same from 1970 to 2000. Thus, fertility decline had a central role in the reduction of income inequality in the country, because it generated a decrease in the proportion of younger age groups in the labor market.

In order to better understand the separate impact of changing age and educational compositions over time in the predicted earnings, a set of figures were estimated. The national age-education proportions, holding age composition constant from 1970 to 2000 and holding educational composition constant from 1970 to 2000, were utilized for this exercise, as well as coefficients from Model (1').

Figures 4 and 5 plot the ratio of predicted earnings from the own-effects model interacted with year (Model (1')) to predicted earnings from the model that includes only indicators for age-education groups and years. The horizontal line is set to be equal to one and shows the model that excludes the proportions in each age-education group. These figures demonstrate that groups with decreasing proportions have gains in earnings and those with growing proportions experience a decline in earnings over time.

Figure 4 demonstrates predictions from Model (1'), holding age distribution constant. Results suggest that the gains and losses in predicted ratios for the several age-education groups have a similar pattern to the original estimates (not shown). Figure 5 shows estimates from 
Model (1'), holding education distribution constant from 1970 to 2000. In this case, it is clear that for the education group (zero to four years of schooling) that had greater proportions in 1970, the new predicted earnings are lower compared to the ones without holding education constant (not shown). On the other hand, groups with lower proportions in 1970 (five to eight years of schooling and at least nine years of schooling) have higher predicted ratios than previous results.

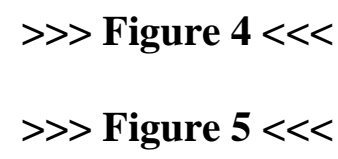

\section{Inequality of income distribution among age-education groups}

Gini coefficients were calculated in order to measure the inequality of the income distribution among age-education groups. The income is more equally distributed among groups, when the coefficient is closer to zero. When the coefficient is closer to one, the income is more unequally distributed. A coefficient equal to zero corresponds to perfect income equality, i.e. everyone has the same income. A coefficient equal to one indicates a perfect income inequality, i.e. one group has all the income, while everyone else has zero income. These coefficients are a more appropriate measure for estimating income inequality than the predicted earnings presented in Table 4. This improvement happens because Gini coefficients take into account not only the income distributions, but also the specific national age-education distributions used to calculate those predicted earnings.

More specifically, Gini coefficients used: (1) predicted national earnings from Model (1') in Table 4; (2) original national age-education distribution in 1970 and 2000; (3) national ageeducation distribution, keeping age composition constant from 1970 to 2000; and (4) national 
age-education composition, holding education distribution constant from 1970 to 2000. Table 5 summarizes all estimated Gini coefficients.

\section{>> Table $5<<<$}

Considering the age-education distribution, results indicate that the income inequality decreased from 1970 to 2000 among the 12 age-education groups by 25 percent (from 0.547 to 0.411). If the age composition had remained the same from 1970 to 2000 , the income inequality would have experienced a smaller decrease from 0.547 to 0.459 , than the one observed when both age and education changed over time. This would have been a decline of only 16 percent.

Considering the education-age distribution, the income inequality decreased from 0.813 in 1970 to 0.414 in 2000 (a reduction of 49 percent), among the 12 age-education groups. If the education composition had remained constant from 1970 to 2000, the income inequality would have had a smaller decrease from 0.813 to 0.783 . Thus, the decline would have only been four percent.

These numbers show that population aging had an important impact in the reduction of inequality in Brazil. Moreover, the improvement in educational attainment had a great impact on the decline of income inequality in the country.

\section{Differences in the male population distribution and earnings by race}

An important aspect of Brazilian income inequality is related to the differences in the male population distribution in age-education groups by race. The 1970 Census does not have information on the color or race characteristics of respondents. The 1980 Census has the variable “color” (cor) with categories “white” (branca), "black” (preta), "yellow” (amarela — Asian), and "brown" (parda). The 1991 and 2000 Censuses added the category "indigenous" (indigena) 
to the ones available from the 1980 Census and identify the variable as "color or race" (cor ou raça). Here this variable will be denominated as race.

The brown category had a growth above the expected vegetative growth over time (Carvalho, Wood, and Andrade 2003; Carvalho, Wood, and Andrade 2004; Wood and Carvalho 1994). The authors suspected that because the black population experienced economic improvement over the years and due to the stereotype of poverty associated to the black race, that some individuals might have identified themselves as brown. Moreover, the black identity classification seems to have been increasing in recent years, perhaps due to the ideological work done by black civil equality movements in the 1990s. Furthermore, the possibility exists that due to the decline in the stereotype of being brown, people who identified themselves as white in the past are now classifying their race as brown. Any racial analysis based on Demographic Census data is limited, because of the instability that exists regarding race classification over time. An awareness of this limitation and as a method for investigating the available data, brown and black categories are aggregated in one single category in this study. This aggregation is called "nonwhite." People classified as yellow or indigenous are not included in the following analysis, because they constitute a small proportion in the population. Among males between 15 and 64 years of age, only 0.69 percent was classified as yellow in 1980, 0.50 in 1991, and 0.49 in 2000 . The indigenous group varied from 0.18 percent in 1991 to 0.42 percent in 2000 , indicating that this group may also struggle with prejudice issues relating to self-identification.

Figure 6 presents the male population distribution by age-education group and race from 1980 to 2000 . The proportion of males in the lowest education group (zero to four years of schooling) has been decreasing over time and the proportion in the other groups has been increasing over time. Furthermore, the distribution by race illustrates that there is a higher 
proportion of the non-white population in the lowest education group, for all age groups, compared to the white population. Also relating to this pattern, the proportion of the white population is larger in the groups with five to eight years of schooling and at least nine years of schooling, compared to non-white.

Figure 7 suggests the mean real monthly earnings of the male population by ageeducation group and race from 1980 to 2000. Levels and patterns of mean earnings might be influenced by drastic variations among individuals, within each age-education group. However, even with this limitation, Figure 7 is a tool which provides a significant idea about earning differences between non-white and whites. In all age-education groups for all Censuses, earnings for white males are greater than the ones observed for non-white males.

\section{$>>$ Figure $6<<<$ \\ >> Figure $7<<<$}

\section{Final considerations}

The aim of this paper was to consider different aspects of the Brazilian population and economy, in order to deepen previous analysis (Amaral et al. 2007). A decomposition of the impact of changing age and education structures on earnings was provided. Gini coefficients were estimated to assess the degree of the income inequality reduction, due to declines in fertility and increases in educational attainment. The male population distribution and mean earnings by age-education groups and race were analyzed, in order to understand racial differentials within the society.

The main results of the paper indicate that improvements in educational attainment from 1970 to 2000 were important factors in reducing economic inequality. While an increase of 
better-educated workers resulted in their having a lower income, a reduction in the number of workers with the lowest education prevented an even lower income for these groups. At the same time, fertility decline played a central role in the reduction of income inequality in Brazil. A smaller proportion of groups consisting of younger workers in the labor market improved their earnings. Thus, the aging of the population also had an important impact on decreasing inequality.

As is implied by the decomposition of economic outcomes, improvement in educational attainment is necessary to increase workers' earnings, taking into account that the changes in age structure also have an impact on income distribution. These results provide some insight that could assist in implementing policies that would further decrease income inequality in the country. Since great variation in age and educational compositions across Brazilian microregions continue, the improvement of educational attainment in areas that still have large proportions of people with lower levels of schooling should become the focus of governmental policies. More specifically, the various levels of government should be concerned with the need to invest in elementary and secondary schooling, since the overall attainment level is still low in Brazil. The quality of education between the public and private sectors still varies greatly. Finally, the analysis of population distribution and mean earnings by race is an indication that changes in age-education composition have been occurring at different levels for the nonwhite population compared to whites. Public policy efforts could concentrate on affirmative action programs to assist the non-white population living in areas with slower transitions relating to the age-education structure. For example, several Brazilian universities have already implemented policies to help facilitate the entrance of non-white students. Some university policies require that a minimum percentage of non-white students enter the school. Other 
universities add points to the admission exams of students who studied in public secondary schools, and also award additional points for those who both self-classify themselves as nonwhite and received public schooling. Future studies are necessary to deepen the analysis of the consequences of changing age and educational composition by race. 


\section{References}

Alves, J.E.D. (2008). A Transição Demográfica e a Janela de Oportunidade. Cadernos de Pesquisa do Instituto Fernand Braudel de Economia Mundial.

Alves, J.E.D., Vasconcelos, D.S., \& Carvalho, A.A. (2010). Estrutura Etária, Bônus Demográfico e População Economicamente Ativa no Brasil: Cenários de Longo Prazo e suas Implicações para o Mercado de Trabalho. Textos para Discussão CEPAL-IPEA, 10.

Amaral, E.F.L., Hamermesh, D.S., Potter, J.E., \& Rios-Neto, E.L.G. (2007). Demographic Change and the Structure of Wages: A Demand-Theoretic Analysis for Brazil. NBER Working Paper Series, 13533.

Berger, M. (1985). The Effect of Cohort Size on Earnings Growth: A Reexamination of the Evidence. The Journal of Political Economy, 93(3), 561-573.

Bloom, D.E., Canning, D., \& Sevilla, J. (2003). The Demographic Dividend: A New Perspective on the Economic Consequences of Population Change. Santa Monica, CA: RAND.

Bloom, D.E., \& Williamson, J. (1998). Demographic Transitions and Economic Miracles in Emerging Asia. World Bank Economics Review, 12, 419-456.

Bloom, D.E., \& Freeman, R.B. (1986). The Effects of Rapid Population Growth on Labor Supply and Employment in Developing Countries. Population and Development Review, 12(3), 381-414.

Bloom, D.E., Canning, D., \& Malaney, P.N. (2000). Population Dynamics and Economic Growth in Asia. Population and Development Review, 26(Supplement), 257-290.

Carvalho, J.A.M., \& Garcia, R.A. (2003). The Aging Process in the Brazilian Population: a Demographic Approach. Cadernos de Saúde Pública, 19(3), 725-733.

Carvalho, J.A.M., \& Wong, L. (1999). Demographic and Socioeconomic Implications of the Rapid Fertility Decline in Brazil: a Window of Opportunity. In: G. Martine, M. Gupta and L. Chenn (Eds.), Reproductive Change in India and Brazil. Oxford: Oxford University Press.

Carvalho, J.A.M, Wood, C.H., \& Andrade, F.C.D. (2003). Notas Acerca das Categorias de Cor dos Censos e Sobre a Classificação Subjetiva de Cor no Brasil: 1980/90. Revista Brasileira de Estudos de População, 20(1), 29-42.

Carvalho, J.A.M., Wood, C.H., \& Andrade, F.C.D. (2004). Estimating the Stability of CensusBased Racial/Ethnic Classifications: the Case of Brazil. Population Studies, 58(3), 331343.

Corseuil, C.H., \& Foguel, M.N. (2002). Uma Sugestão de Deflatores para Rendas Obtidas a Partir de Algumas Pesquisas Domiciliares do IBGE. Texto para Discussão, 897. Rio de Janeiro: Brazilian Institute of Applied Economic Research (Instituto de Pesquisa Econômica Aplicada - IPEA).

Easterlin, R.A. (1978). What Will 1984 Be Like? Socioeconomic Implications of Recent Twists in Age Structure. Demography, 15(4), 397-432.

Freeman, R.B. (1979). The Effect of Demographic Factors on Age-Earnings Profiles. The Journal of Human Resources, 14(3), 289-318.

Hamermesh, D. (1993). Labor Demand. Princeton: Princeton University Press.

Higgins, M., \& Williamson, J.G. (1997). Age Structure Dynamics in Asia and Dependence on Foreign Capital. Population and Development Review, 23(2), 261-293. 
Kelley, A.C. (2003). The Population Debate in Historical Perspective: Revisionism Revised. In N. Birdsall, A.C. Kelley and S.W. Sinding (Eds.), Population Matters. Oxford: Oxford University Press.

Malthus, T.K. (1985). An Essay on the Principle of Population. Harmondsworth, Middlesex, UK: Penguin Classics.

Mason, A. (2005). Demographic Transition and Demographic Dividends in Developed and Developing Countries. Population Division / Department of Economic and Social Affairs / United Nations, UN/POP/PD/2005/2.

Mason, A., \& Feng, W. (2005). Demographic Dividends and China's Post Reform Economy. Paper presented at the XXV IUSSP General Population Conference, Tours, France, 18-23 July.

Mincer, J. (1974). Schooling, Experience, and Earnings. New York: National Bureau of Economic Research.

Moreira, M.M. (2001). Structural Changes in the Brazilian Age Distribution: 1950-2050. Paper presented at the XXIV IUSSP General Population Conference, Salvador, Brazil, 18-24 August.

Potter, J.E., Schmertmann, C.P., \& Cavenaghi, S.M. (2002). Fertility and Development: Evidence From Brazil. Demography, 39, 739-761.

Potter, J.E., Schmertmann, C.P., Assunção, R.M., \& Cavenaghi, S.M. (2010). Mapping the Timing, Pace, and Scale of the Fertility Transition in Brazil. Population and Development Review, 36(2), 283-307.

Queiroz, B.L., \& Turra, C.M. (2010). Window of Opportunity: Socioeconomic Consequences of Demographic Changes in Brazil. Paper Presented at the IUSSP Seminar-Demographics and Macroeconomic Performance, Paris, France, 4-5 June.

Triest, R.K., Sapozhnikov, M., \& Sass, S.A. (2006). Population Aging and the Structure of Wages. Manuscript. Chestnut Hill, MA: Center for Retirement Research at Boston College.

Turra, C.M., \& Queiroz, B.L. (2009). Antes de Que Sea Demasiado Tarde: Transición Demográfica, Mano de Obra Disponible y Problemas de la Seguridad Social en el Brasil. Notas de Población, 86, 141-165.

Welch, F. (1979). Effects of Cohort Size on Earnings: The Baby Boom Babies' Financial Bust. The Journal of Political Economy, 87(5), 2, S65-S97.

Williamson, J.G. (2003). Demographic Change, Economic Growth, and Inequality. In N. Birdsall, A.C. Kelley and S.W. Sinding (Eds.), Population Matters. Oxford: Oxford University Press.

Wong, L., \& Carvalho, J.A.M. (2005). Demographic Bonuses and Challenges of the Age Structural Transition in Brazil. Paper presented at the XXV IUSSP General Population Conference, Tours, France, 18-23 July.

Wood, C.H., \& Carvalho, J.A.M. (1994). Categorias do Censo e Classificação Subjetiva de Cor no Brasil. Revista Brasileira de Estudos de População, 11(1), 3-17. 
Table 1. Total Fertility Rate, Infant Mortality Rate and Life Expectancy at Birth, Brazil, 19502050.

\begin{tabular}{c|ccc}
\hline Period & $\begin{array}{c}\text { Total } \\
\text { Fertility Rate }\end{array}$ & $\begin{array}{c}\text { Infant Mortality } \\
\text { Rate (per 1,000 births) }\end{array}$ & $\begin{array}{c}\text { Life Expectancy } \\
\text { at Birth (years) }\end{array}$ \\
\hline $1950-1955$ & 6.15 & 134.7 & 50.9 \\
$1955-1960$ & 6.15 & 121.9 & 53.3 \\
$1960-1965$ & 6.15 & 109.4 & 55.7 \\
$1965-1970$ & 5.38 & 100.1 & 57.6 \\
$1970-1975$ & 4.72 & 90.5 & 59.5 \\
$1975-1980$ & 4.31 & 78.8 & 61.5 \\
$1980-1985$ & 3.8 & 63.3 & 63.1 \\
$1985-1990$ & 3.1 & 52.4 & 64.9 \\
$1990-1995$ & 2.6 & 42.5 & 66.6 \\
$1995-2000$ & 2.45 & 34.1 & 68.8 \\
$2000-2005$ & 2.35 & 27.4 & 70.3 \\
$2005-2010$ & 2.25 & 23.6 & 71.9 \\
$2010-2015$ & 2.15 & 20.3 & 72.9 \\
$2015-2020$ & 2.06 & 17.1 & 74.2 \\
$2020-2025$ & 1.98 & 14.3 & 75.2 \\
$2025-2030$ & 1.92 & 12.1 & 76.2 \\
$2030-2035$ & 1.86 & 10.3 & 77 \\
$2035-2040$ & 1.85 & 9.1 & 79.8 \\
$2040-2045$ & 1.85 & 8.1 & 79.2 \\
$2045-2050$ & 1.85 & 7.5 &
\end{tabular}

Source: United Nations - http://esa.un.org/unpp (medium variant). 
Figure 1. Dependency Ratios, Brazil, 1950-2050.

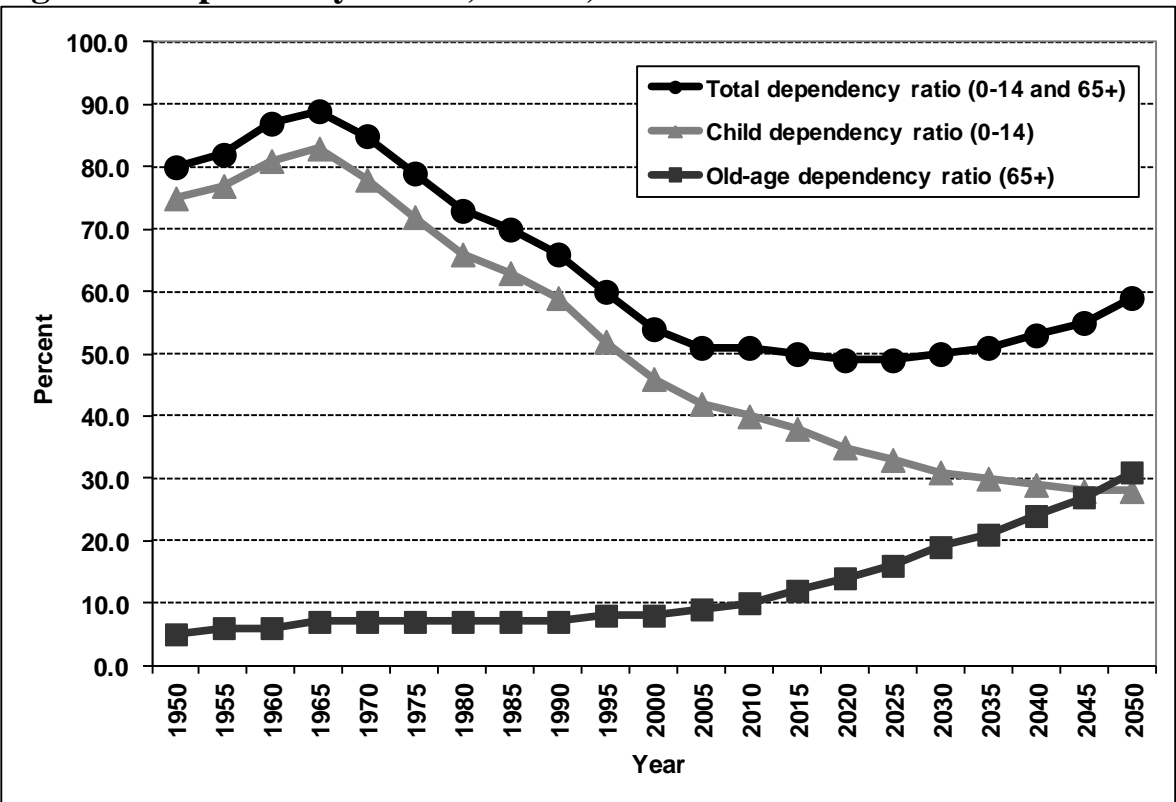

Source: United Nations — http://esa.un.org/unpp (medium variant). 
Table 2. Distribution of Male Population by Year and Age-Education Group, 1970-2000.

\begin{tabular}{|c|c|c|c|c|}
\hline $\begin{array}{l}\text { Age-education } \\
\text { Group }\end{array}$ & 1970 & 1980 & 1991 & 2000 \\
\hline $\begin{array}{c}15-24 \text { years } \\
0-4 \text { years of schooling }\end{array}$ & 28.19 & 20.59 & 14.61 & 9.04 \\
\hline $\begin{array}{c}15-24 \text { years } \\
5-8 \text { years of schooling }\end{array}$ & 5.38 & 10.53 & 12.09 & 12.46 \\
\hline $\begin{array}{c}15-24 \text { years } \\
9+\text { years of schooling }\end{array}$ & 2.74 & 5.87 & 5.97 & 10.24 \\
\hline $\begin{array}{c}25-34 \text { years } \\
0-4 \text { years of schooling }\end{array}$ & 19.71 & 16.39 & 12.41 & 8.82 \\
\hline $\begin{array}{c}25-34 \text { years } \\
5-8 \text { years of schooling }\end{array}$ & 1.98 & 3.90 & 6.82 & 7.63 \\
\hline $\begin{array}{c}25-34 \text { years } \\
9+\text { years of schooling }\end{array}$ & 2.00 & 4.77 & 7.40 & 8.12 \\
\hline $\begin{array}{c}35-49 \text { years } \\
0-4 \text { years of schooling }\end{array}$ & 22.66 & 19.02 & 17.11 & 13.32 \\
\hline $\begin{array}{c}35-49 \text { years } \\
5-8 \text { years of schooling }\end{array}$ & 1.62 & 2.39 & 3.67 & 6.73 \\
\hline $\begin{array}{c}35-49 \text { years } \\
9+\text { years of schooling }\end{array}$ & 1.59 & 2.84 & 5.54 & 8.46 \\
\hline $\begin{array}{c}50-64 \text { years } \\
0-4 \text { years of schooling }\end{array}$ & 12.84 & 11.72 & 11.49 & 10.36 \\
\hline $\begin{array}{c}50-64 \text { years } \\
5-8 \text { years of schooling }\end{array}$ & 0.65 & 0.94 & 1.16 & 1.99 \\
\hline $\begin{array}{c}50-64 \text { years } \\
9+\text { years of schooling }\end{array}$ & 0.62 & 1.05 & 1.72 & 2.84 \\
\hline Total & $25,760,600$ & $32,613,947$ & $43,434,534$ & $53,177,963$ \\
\hline
\end{tabular}

Source: 1970, 1980, 1991 and 2000 Brazilian Demographic Censuses. 
Figure 2. Proportion of Men Ages 25-34 with 9+ Years of Schooling in 502 Micro-regions ${ }^{\text {a }}$, Brazil, 1970-2000.

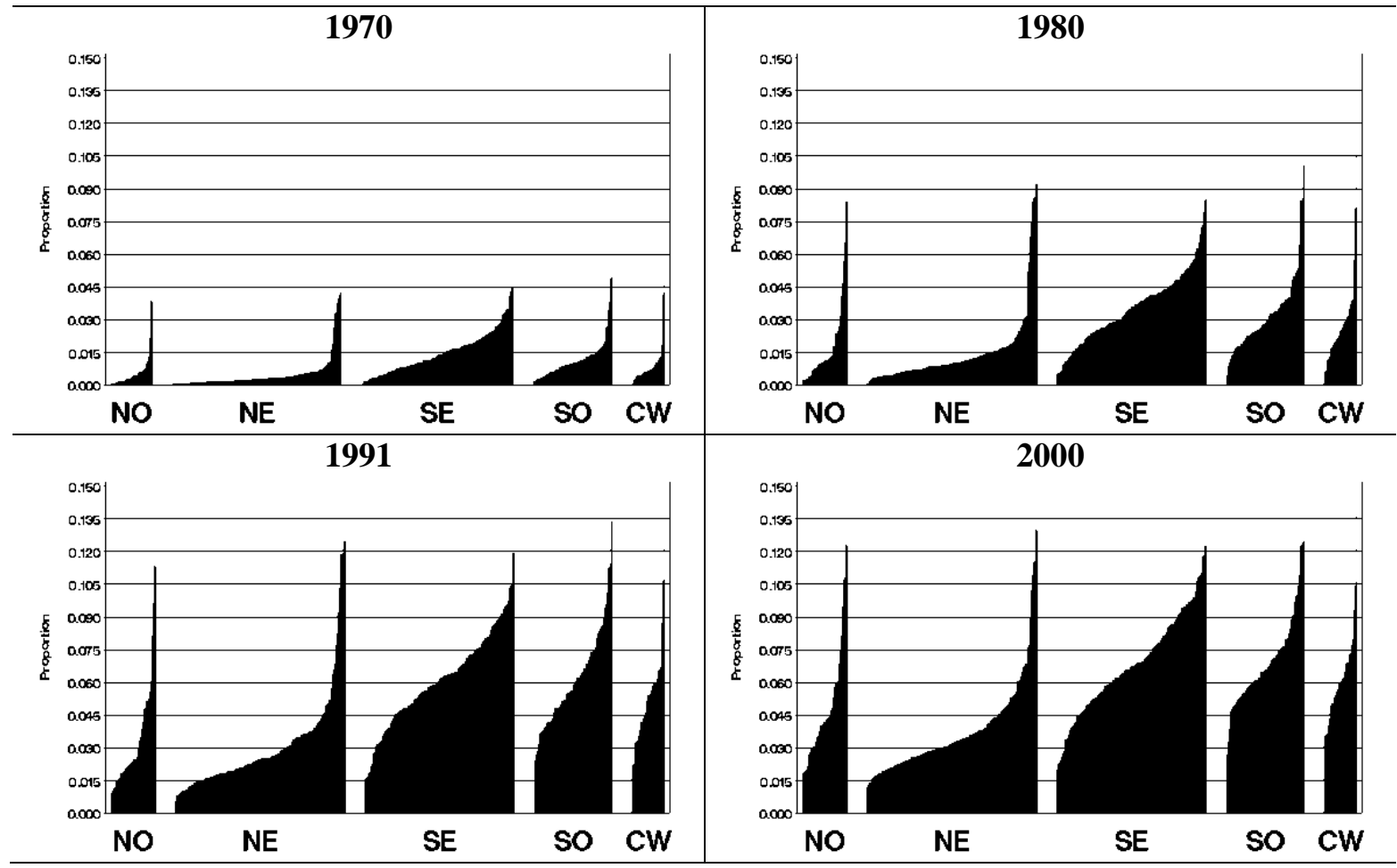

\footnotetext{
${ }^{a}$ For a better understanding of the figures, micro-regions are ordered by five Brazilian regions: North (NO), Northeast (NE), Southeast (SE), South (SO), and Central-West (CW).

Source: 1970, 1980, 1991 and 2000 Brazilian Demographic Censuses.
} 
Figure 3. Proportion of Men Ages 35-49 with 0-4 Years of Schooling in 502 Micro-regions ${ }^{\text {a }}$ Brazil, 1970-2000.

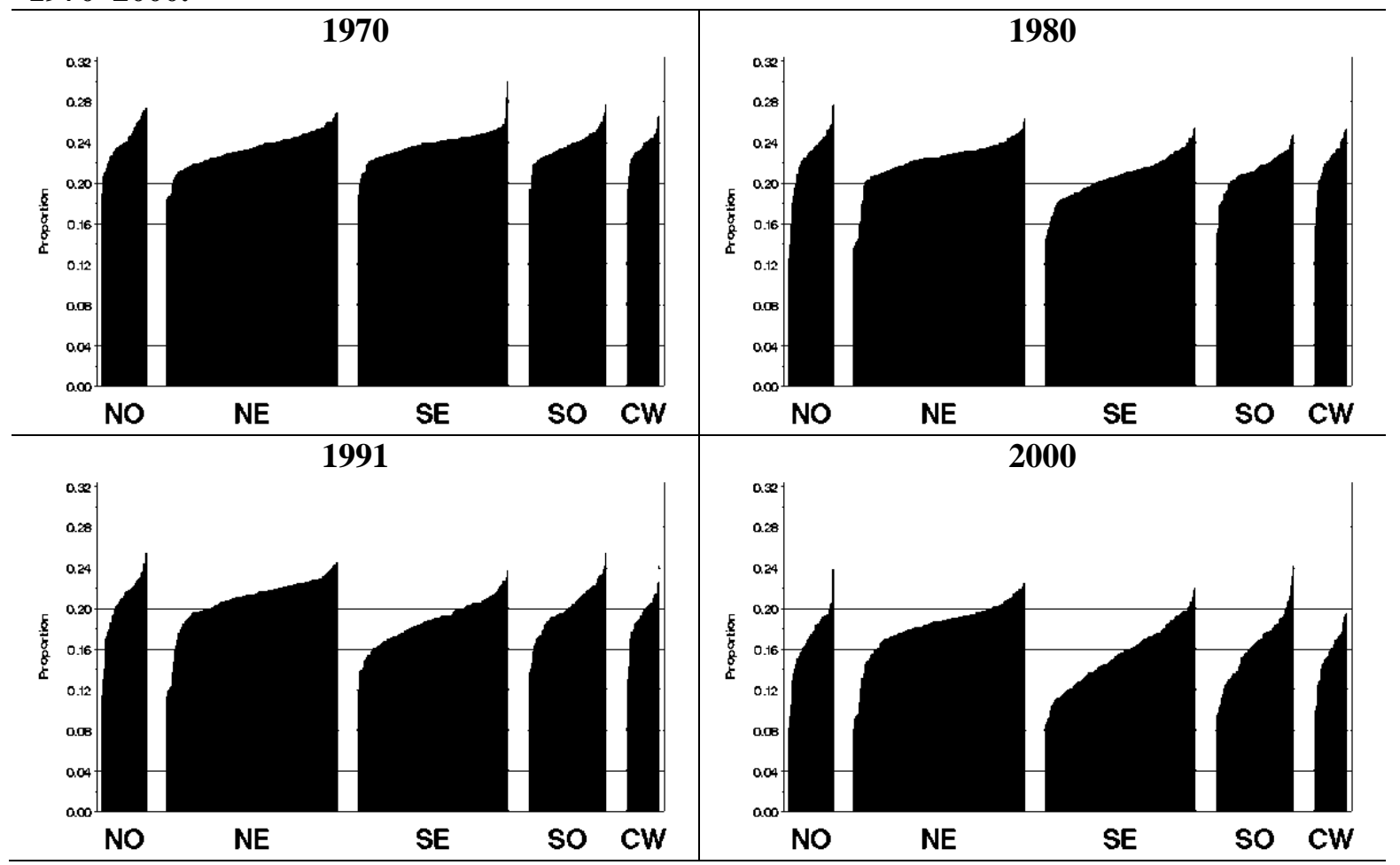

\footnotetext{
${ }^{a}$ For a better understanding of the figures, micro-regions are ordered by five Brazilian regions: North (NO), Northeast (NE), Southeast (SE), South (SO), and Central-West (CW).
}

Source: 1970, 1980, 1991 and 2000 Brazilian Demographic Censuses. 
Table 3. Summary of $\boldsymbol{F}$-Statistics from the Model Only With Age-Education-Group and Year Indicators, from Models (1), (1'), (2), (2'), and from Models Including Interactions With Microregion Size and Region Indicators, Brazil, 1970-2000.

\begin{tabular}{|c|c|c|c|}
\hline Models & All Coefficients $=0$ & $\begin{array}{l}\text { Area Fixed Effects }=0 \\
\left(\text { F-Test that All } v_{i}=0\right)\end{array}$ & $\begin{array}{l}\text { Rho: Fraction of } \\
\text { Variance Due to the } v_{i}\end{array}$ \\
\hline $\begin{array}{l}\text { Model only with year and } \\
\text { age-education indicators }\end{array}$ & $\begin{array}{c}\mathrm{F}(14 ; 19,211): \\
12,941.99 * * *\end{array}$ & $\begin{array}{c}\mathrm{F}(501 ; 19,211): \\
65.13 * * *\end{array}$ & 0.66 \\
\hline $\begin{array}{l}\text { Model (1): } \\
\text { Own-effects }\end{array}$ & $\begin{array}{l}\mathrm{F}(26 ; 19,199): \\
8,506.08 * * *\end{array}$ & $\begin{array}{c}\mathrm{F}(501 ; 19,199): \\
57.02 * * *\end{array}$ & 0.73 \\
\hline $\begin{array}{c}\text { Model (1'): } \\
\text { Own-effects X Year }\end{array}$ & $\begin{array}{c}\mathrm{F}(62 ; 19,163): \\
3,957.16^{* * *}\end{array}$ & $\begin{array}{c}\mathrm{F}(501 ; 19,163): \\
53.20 * * *\end{array}$ & 0.74 \\
\hline $\begin{array}{l}\text { Model (2): } \\
\text { Cross-effects }\end{array}$ & $\begin{array}{c}\mathrm{F}(146 ; 19,079): \\
1,808.52 * * *\end{array}$ & $\begin{array}{c}\mathrm{F}(501 ; 19,079): \\
20.82 * * *\end{array}$ & 0.68 \\
\hline $\begin{array}{c}\text { Model (2’): } \\
\text { Cross-effects X Year }\end{array}$ & $\begin{array}{l}\mathrm{F}(542 ; 18,683): \\
538.51^{* * *}\end{array}$ & $\begin{array}{l}\mathrm{F}(501 ; 18,683): \\
20.87 * * *\end{array}$ & 0.66 \\
\hline $\begin{array}{c}\text { Model (1) } \\
\text { X Region indicators }\end{array}$ & $\begin{array}{c}\mathrm{F}(74 ; 19,151): \\
3,169.42 * * *\end{array}$ & $\begin{array}{c}\mathrm{F}(501 ; 19,151): \\
27.40 * * *\end{array}$ & 0.69 \\
\hline $\begin{array}{c}\text { Model (1') } \\
\text { X Region indicators }\end{array}$ & $\begin{array}{c}\mathrm{F}(266 ; 18,959): \\
1,023.04 * * *\end{array}$ & $\begin{array}{c}\mathrm{F}(501 ; 18,959): \\
25.76^{* * *}\end{array}$ & 0.68 \\
\hline $\begin{array}{c}\text { Model (2) } \\
\text { X Region indicators }\end{array}$ & $\begin{array}{l}\mathrm{F}(674 ; 18,551): \\
\quad 423.38^{* * *}\end{array}$ & $\begin{array}{c}\mathrm{F}(501 ; 18,551): \\
13.65 * * *\end{array}$ & 0.89 \\
\hline $\begin{array}{c}\text { Model (2') } \\
\text { X Region indicators }\end{array}$ & $\begin{array}{c}\mathrm{F}(2,630 ; 16,595): \\
125.77 * * *\end{array}$ & $\begin{array}{l}\mathrm{F}(501 ; 16,595): \\
12.19 * * *\end{array}$ & 0.98 \\
\hline $\begin{array}{c}\text { Model (1) } \\
\text { X Micro-region size }\end{array}$ & $\begin{array}{c}\mathrm{F}(65 ; 19,160): \\
3,510.03 * * *\end{array}$ & $\begin{array}{c}\mathrm{F}(501 ; 19,160): \\
55.16^{* * *}\end{array}$ & 0.73 \\
\hline $\begin{array}{c}\text { Model (1') } \\
\text { X Micro-region size }\end{array}$ & $\begin{array}{c}\mathrm{F}(214 ; 19,011): \\
1,172.15^{* * *}\end{array}$ & $\begin{array}{l}\mathrm{F}(501 ; 19,011): \\
50.75^{* * *}\end{array}$ & 0.73 \\
\hline $\begin{array}{c}\text { Model (2) } \\
\text { X Micro-region size }\end{array}$ & $\begin{array}{l}\mathrm{F}(545 ; 18,680): \\
\quad 504.12 * * *\end{array}$ & $\begin{array}{l}\mathrm{F}(501 ; 18,680): \\
20.53 * * *\end{array}$ & 0.71 \\
\hline $\begin{array}{c}\text { Model (2') } \\
\text { X Micro-region size }\end{array}$ & $\begin{array}{c}\mathrm{F}(2,040 ; 17,185): \\
150.08 * * *\end{array}$ & $\begin{array}{l}\mathrm{F}(501 ; 17,185): \\
19.26 * * *\end{array}$ & 0.68 \\
\hline
\end{tabular}

${ }^{*}$ Significant at $\mathrm{p}<.05 ;{ }^{* *}$ Significant at $\mathrm{p}<.01 ;{ }^{* * *}$ Significant at $\mathrm{p}<.001$. Source: 1970, 1980, 1991 and 2000 Brazilian Demographic Censuses. 
Table 4. Effects of Age and Education Distributions on Predicted Earnings a from Model (1') by Age-Education Groups, Brazil, 1970 and 2000.

\begin{tabular}{|c|c|c|c|c|}
\hline \multirow[b]{2}{*}{$\begin{array}{l}\text { Age-Education } \\
\text { Group }\end{array}$} & \multirow{2}{*}{$\begin{array}{l}1970 \text { Actual } \\
\text { Predicted Earnings } \\
\text { (in Brazilian Reais) }\end{array}$} & \multicolumn{3}{|c|}{2000 Predicted Earnings (in Brazilian Reais) Using: } \\
\hline & & $\begin{array}{l}2000 \text { Actual } \\
\text { Age-Education } \\
\text { Distribution } \\
\end{array}$ & $\begin{array}{l}2000 \text { Actual Education, } \\
\text { and } 1970 \text { Age } \\
\text { Distribution }\end{array}$ & $\begin{array}{l}2000 \text { Actual Age, } \\
\text { and } 1970 \text { Education } \\
\text { Distribution }\end{array}$ \\
\hline $\begin{array}{c}15-24 \text { years } \\
0-4 \text { years of schooling }\end{array}$ & 161.01 & 206.49 & 204.45 & 192.58 \\
\hline $\begin{array}{c}15-24 \text { years } \\
5-8 \text { years of schooling }\end{array}$ & 254.35 & 268.63 & 245.19 & 409.39 \\
\hline $\begin{array}{c}15-24 \text { years } \\
9+\text { years of schooling }\end{array}$ & 430.20 & 321.84 & 299.68 & 469.45 \\
\hline $\begin{array}{c}25-34 \text { years } \\
0-4 \text { years of schooling }\end{array}$ & 225.60 & 312.56 & 314.13 & 271.04 \\
\hline $\begin{array}{c}25-34 \text { years } \\
5-8 \text { years of schooling }\end{array}$ & 533.62 & 445.95 & 454.15 & 629.99 \\
\hline $\begin{array}{c}25-34 \text { years } \\
9+\text { years of schooling }\end{array}$ & $1,040.79$ & 812.09 & 815.46 & 887.72 \\
\hline $\begin{array}{c}35-49 \text { years } \\
0-4 \text { years of schooling }\end{array}$ & 269.80 & 404.40 & 414.40 & 310.07 \\
\hline $\begin{array}{c}35-49 \text { years } \\
5-8 \text { years of schooling }\end{array}$ & 788.13 & 609.37 & 642.95 & 898.28 \\
\hline $\begin{array}{c}35-49 \text { years } \\
9+\text { years of schooling }\end{array}$ & $1,536.64$ & $1,281.75$ & $1,328.73$ & $1,729.86$ \\
\hline $\begin{array}{c}50-64 \text { years } \\
0-4 \text { years of schooling }\end{array}$ & 276.26 & 414.27 & 424.84 & 289.37 \\
\hline $\begin{array}{c}50-64 \text { years } \\
5-8 \text { years of schooling }\end{array}$ & 941.57 & 814.89 & 825.19 & 914.27 \\
\hline $\begin{array}{c}50-64 \text { years } \\
9+\text { years of schooling }\end{array}$ & $1,687.24$ & $1,422.78$ & $1,469.16$ & $2,013.55$ \\
\hline
\end{tabular}

${ }^{a}$ Nominal income was converted to base 1 in January 2002, taking into account changes in currency and inflation.

Source: 1970, 1980, 1991 and 2000 Brazilian Demographic Censuses. 
Figure 4. Ratios of Predicted Earnings from Model (1') to Predicted Earnings from Baseline Model, using the National Age-Education Distribution, and Maintaining the 1970 Age Distribution Constant, Brazil, 1970-2000.

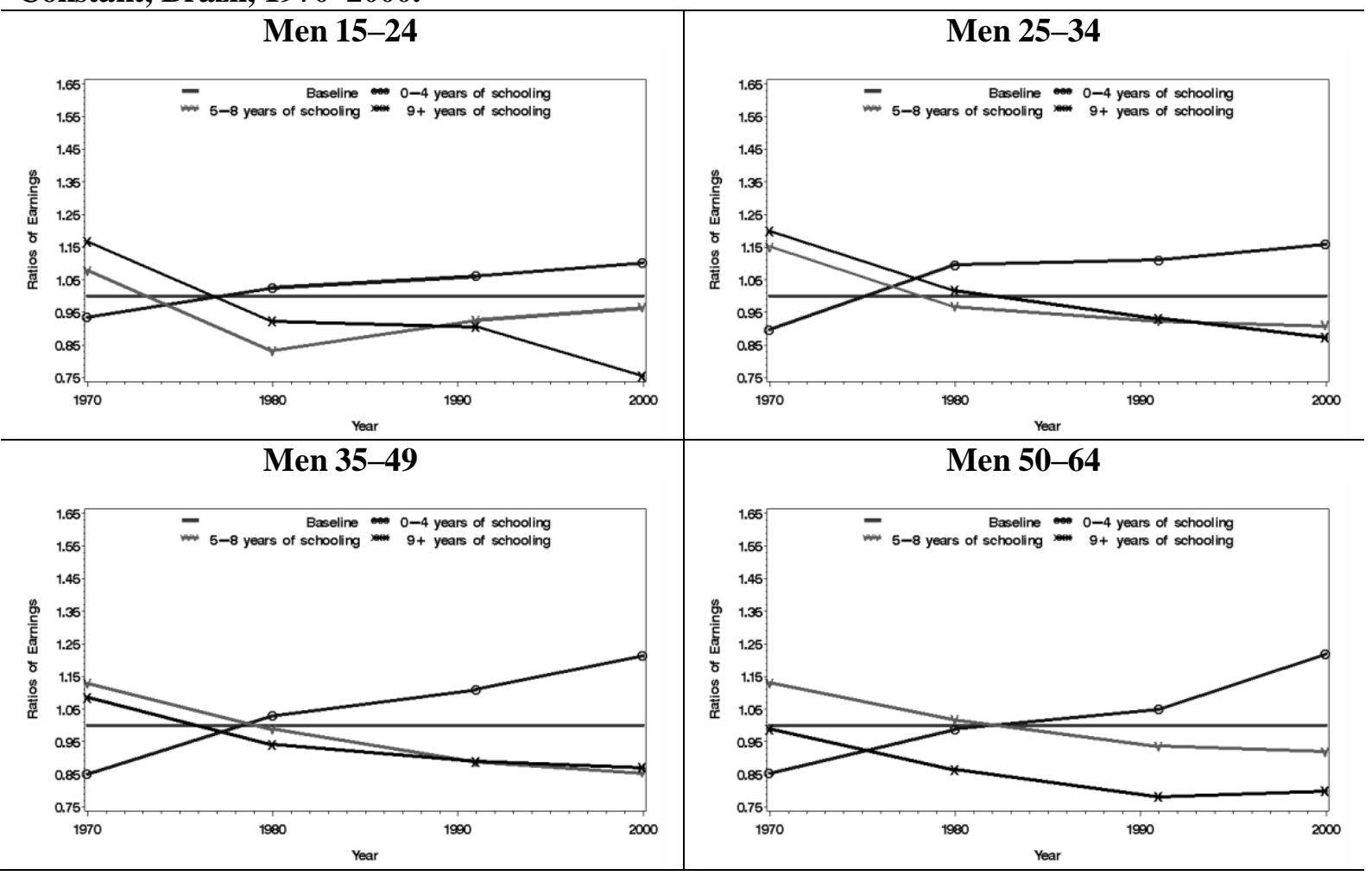

Source: 1970, 1980, 1991 and 2000 Brazilian Demographic Censuses. 
Figure 5. Ratios of Predicted Earnings from Model (1') to Predicted Earnings from Baseline Model, using the National Age-Education Distribution, and Maintaining the 1970 Education Distribution Constant, Brazil, 1970-2000.

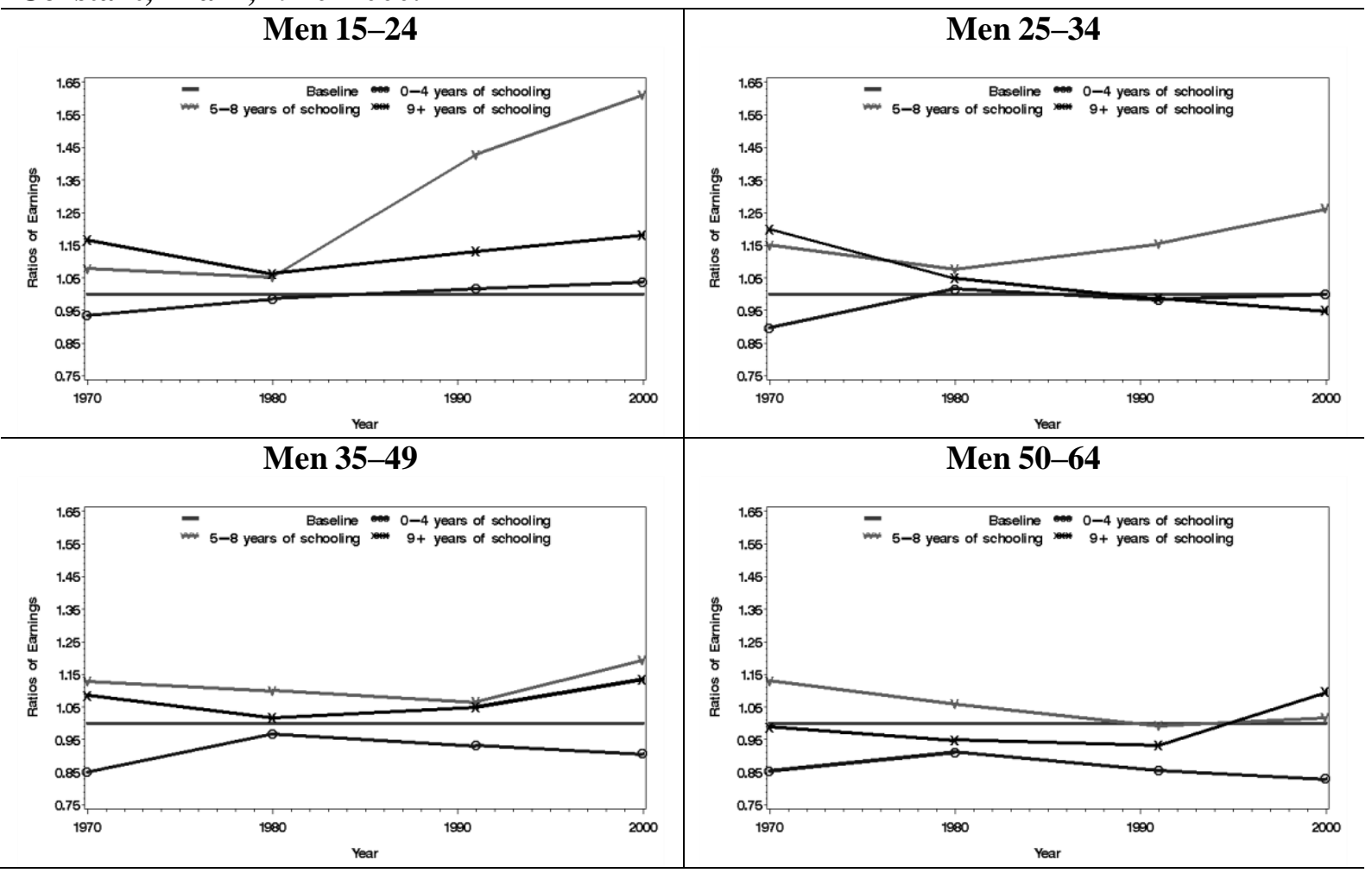

Source: 1970, 1980, 1991 and 2000 Brazilian Demographic Censuses. 
Table 5. Summary of Gini Coefficients Using Predicted National Earnings from Model (1') and National Age-Education Distributions, Brazil, 1970 and 2000.

\begin{tabular}{c|cccc}
\hline \multirow{2}{*}{ Group Order } & \multicolumn{4}{|c}{ Gini Coefficients Using National Distribution from: } \\
& $\mathbf{1 9 7 0}$ & $\mathbf{2 0 0 0}$ & $\begin{array}{c}\text { 1970 Age \& } \\
\mathbf{2 0 0 0} \text { Education }\end{array}$ & $\begin{array}{c}\mathbf{1 9 7 0} \text { Education } \\
\text { \& 2000 Age }\end{array}$ \\
\hline Age-Education & 0.547 & 0.411 & 0.459 & - \\
Education-Age & 0.813 & 0.414 & - & 0.783 \\
\hline
\end{tabular}

Source: 1970, 1980, 1991 and 2000 Brazilian Demographic Censuses. 
Figure 6. Percent of Male Population by Year, Race, and Age-Education Group, Brazil, 1980-2000.

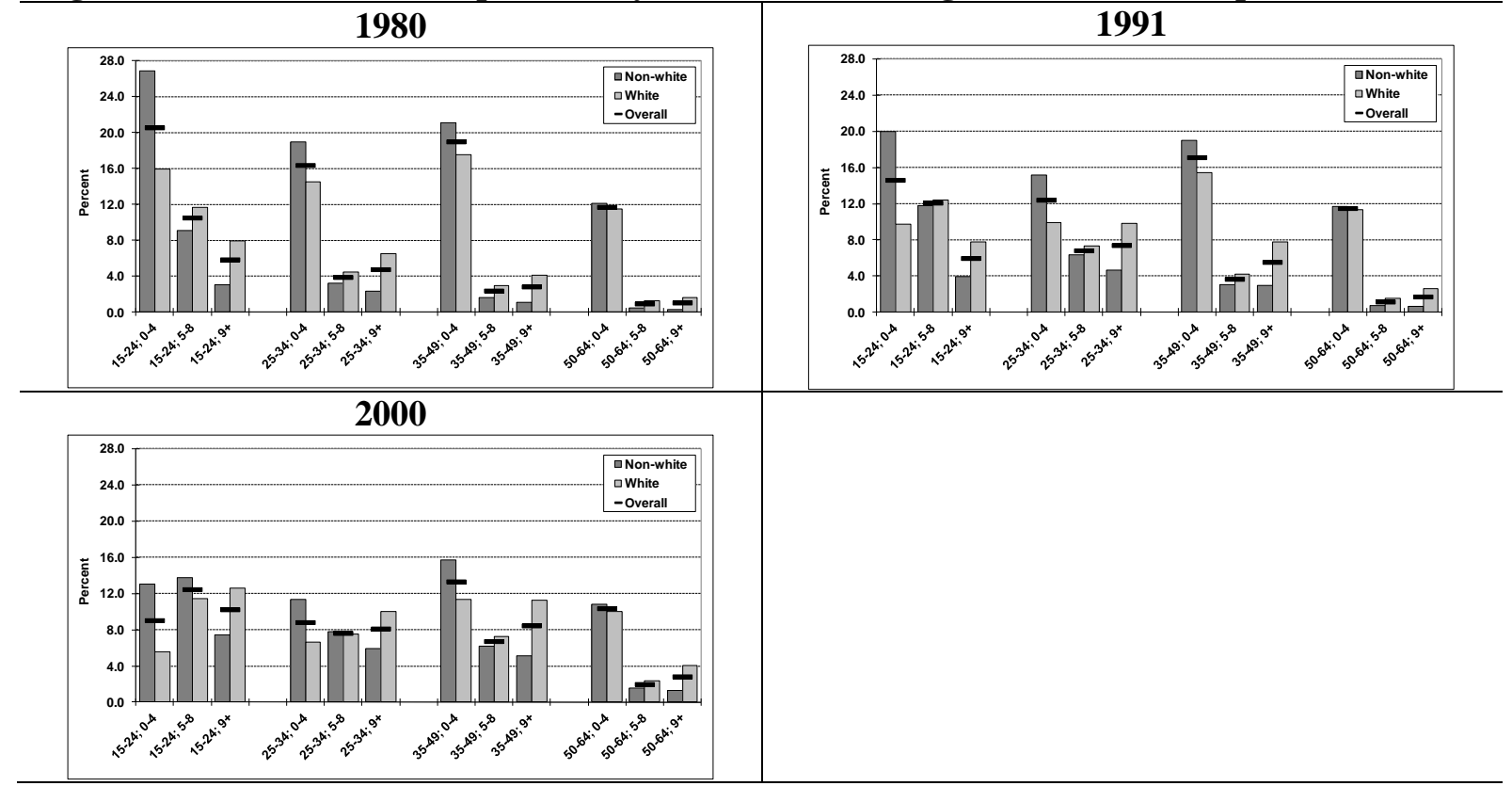

Source: 1980, 1991 and 2000 Brazilian Demographic Censuses. 
Figure 7. Mean Real Monthly Earnings ${ }^{a}$ (in Brazilian Reais) of Male Population by Year, Race, and Age-Education Group, Brazil, 1980-2000.

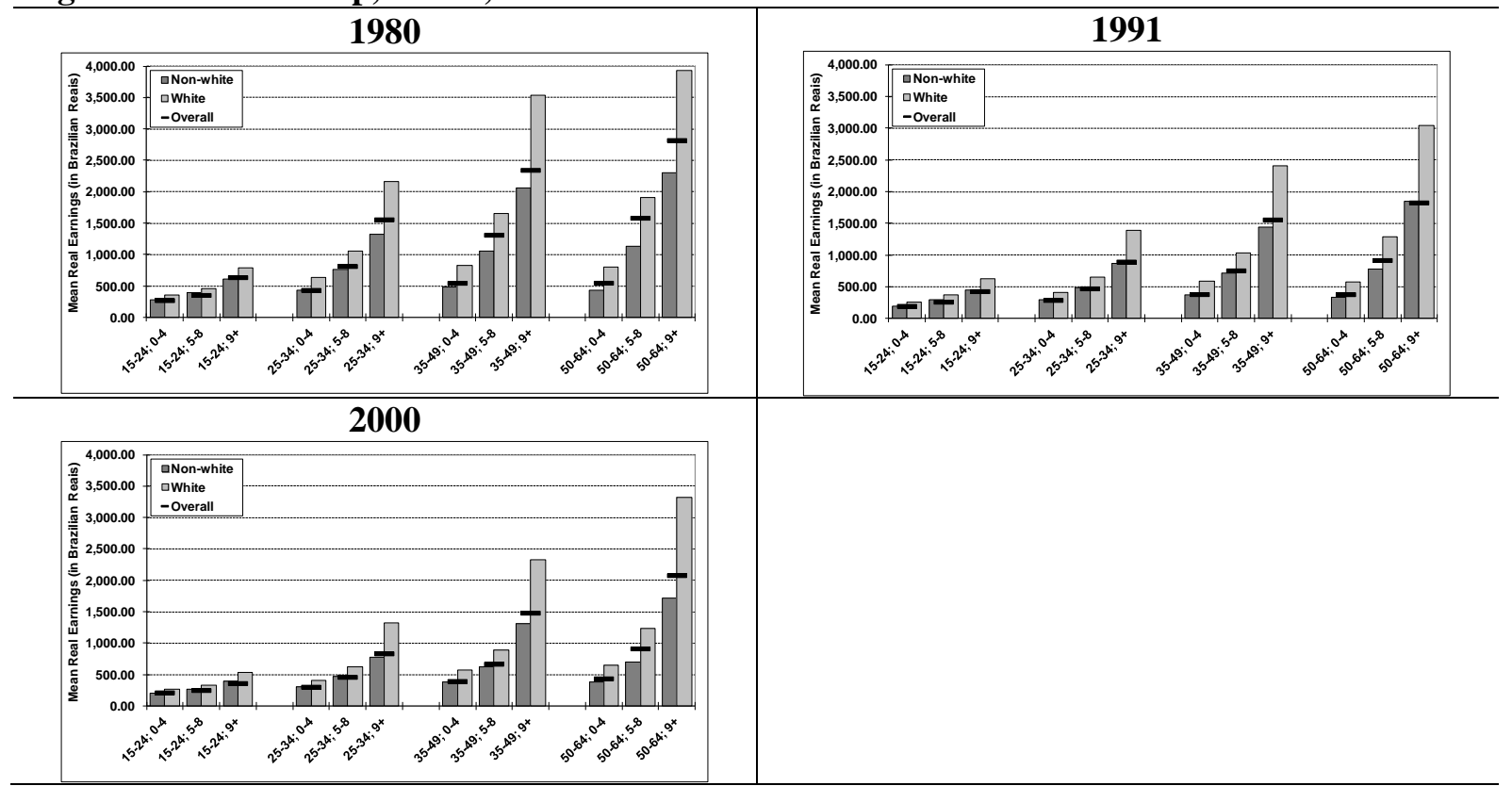

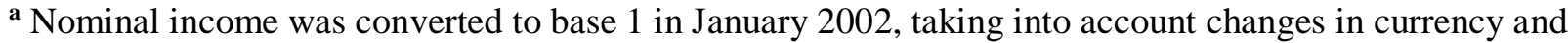
inflation.

Source: 1980, 1991 and 2000 Brazilian Demographic Censuses. 